\title{
The Influence of Seawater on a Coastal Aquifer in an International Protected Area, Göksu Delta Turkey
}

\author{
Zeynel Demirel \\ Mersin University Engineering Faculty, Environmental Engineering Department, Mersin, Turkey \\ E-mail: zdemirel@mersin.edu.tr \\ Received March 22, 2010; revised June 8, 2010; accepted June 15, 2010
}

\begin{abstract}
Göksu Delta is an important wetland where the Göksu River reaches the sea in the eastern part of the town of Tasucu-Ice1. The delta is classified as a Wetland of International Importance according to the Ramsar Convention. In the Göksu Delta area, urban and agricultural expansions have caused an ever-growing need for fresh water. High groundwater pumping rates and overexploitation of the aquifers, leading to seawater mixing in the Göksu coastal aquifers. The chemical types of groundwater from alluvial aquifer are $\mathrm{Ca}-\mathrm{Mg}-\mathrm{HCO}_{3}$, but in the region where sea water mixing is occurred it changes and the $\mathrm{Na}$ and $\mathrm{Cl}$ ions are added to groundwater. The similar occurrence can be observed in the groundwater from the limestone aquifer. The chemical types of groundwater are $\mathrm{Ca}-\mathrm{HCO}_{3}$ or $\mathrm{Ca}-\mathrm{Mg}-\mathrm{HCO}_{3}$ and they change to $\mathrm{Ca}-\mathrm{Na}-\mathrm{Mg}-\mathrm{HCO}_{3}-\mathrm{Cl}$ in the vicinity of seawater mixing regions. A statistical comparative analysis also shows that some of the samples are affected by sea water mixing. The extent of seawater intrusion is reflected by the distribution of salinity and electrical conductivity as an equiconcentration map.
\end{abstract}

Keywords: Göksu Delta-Turkey, Ramsar Convention, Sea Water Intrusion, Statistical Comparative Analysis, Geographic Information System

\section{Introduction}

The Göksu Delta is formed by the Goksu River near the Southern part of Silifke, a town in Turkey's Mediterranean region. Göksu Delta is an important wetland (15000 ha) where the Göksu River reaches the sea in the eastern of the town Tasucu-Ice1 [1].

The Mediterranean coastline stretching from the city of Taşucu to the Susanoğlu region is heavily populated due to urban developments (villas, apartments, complexes, and multi-storey buildings) in the last fifteen years, though most of these structures are occupied only in the summer season for vacation purposes. Because of an increased population influx from the surrounding cities, especially during the peak season (May to September), the population of this region has increased several times.

The Göksu Delta is not only an urban area but it is also surrounded by densely cultivated orchards (mostly citrus), traditional vegetable farms and greenhouse cultivations, where farming activities continue all year long due to the favorable climate.

In the Göksu Delta area, urban and agricultural expansions have caused an ever-growing need for fresh water. In this region, water supply for most municipalities, do- mestic use water for urban developments and irrigated water for agricultural activities are almost exclusively provided through hand dug or drilled wells. Therefore, water resources in the Göksu Delta area are subjected to intensive demands, stresses and pollution risks [2]. The expansion of irrigated agriculture induces the risk of groundwater quality degradation through high groundwater pumping rates and overexploitation of the aquifers, leading to seawater intrusion in the coastal aquifers.

Göksu Delta is an internationally important wetland due to its location being on a bird migration route. The Environmental Protection Department of the Ministry of Environment has declared the Göksu Delta as a Special Environmental Protection Zone to protect the area against pollution and exploitation, and to ensure that natural resources and cultural assets have a future. The delta is classified as a Wetland of International Importance according to the Ramsar Convention on Wetlands of International Importance. The Goksu Delta has also a special significance for being one of the few remaining areas in the world where sea turtles (Caretta caretta, Chelonia mydas) and blue crabs (Callinectes sapidus) lay their eggs $[1,3]$.

Under steady-state conditions, a state of equilibrium is 
established between seawater and freshwater in Göksu coastal alluvial aquifer. However, owing to increasing demand for water, groundwater may be subjected to over-exploitation and the natural equilibrium is thus disturbed. This results in aggressive seawater mixing, which may even reach the inland aquifer.

The purpose of this study is to understand the seawater intrusion into groundwater, to investigate the pollution of groundwater by sea water and pictorially represent it using the geographic information system (GIS).

\section{Site Description}

The Göksu Delta is situated in the Mediterranean Sea region of the southeastern part of Turkey and extends from $36^{\circ} 15-36^{\circ} 25$ of latitude north to $33^{\circ} 55-34^{\circ} 05$ of longitude west. The Göksu Delta area is bounded by the Taurus Mountains on the northern side and by the Mediterranean Sea on the southern and eastern side. The southern portion of the Göksu Delta area is a delta plain made up of sediments from Göksu River. The Goksu River flow regime is strongly dependent on the seasonal rains and temperature. The average flow of Goksu River is $130 \mathrm{~m}^{3} / \mathrm{s}$ where it reaches the highest value during May.

In the Göksu Delta area, climate is characterized by hot and dry periods in the summer and by warm and wet periods in the winter, which is typical for the coastal zones around the Mediterranean Sea. The mean annual temperature in this area is $19^{\circ} \mathrm{C}$. Showers start in October, and continue until mid April and the maximum rainfall occurs in December. The Göksu Delta area receives slightly higher than $607 \mathrm{~mm}$ of precipitation annually, and extended periods (i.e., 3-4 months) without precipitation are common

The study area was located in the southern part of Miocene carbonate rocks of the Taurus Mountains Belt.

The oldest rock unit of the Göksu Delta is the Akdere Formation from the Paleozoic Age, which consists of marble, schist and quartzite. The Akdere Formation (middleupper Devonian) is generally found in the northern part of the study area. Kusyuvasi Formation (Middle Trias) consists of limestone. The Tokmar Formation (upper Jura-lower Cretaceous) is found in the western part of delta and contains dolomite and limestone.

Tertiary units are composed of lower-middle Miocene Karaisali formation and middle-upper Miocene Kuzgun formation (Figure 1). Tertiary rocks consist of a succession of marine, lacustrine and fluvial deposits, which display transitional characteristics both vertically and areally in the study area.

The Quaternary basin-fill deposits are a heterogeneous mixture of metamorphic and sedimentary rock detritus ranging from clay to boulder size. The mixture includes stream alluvium, stream-terrace deposits, fan deposits, delta deposits, shore deposits. The basin-fill deposits vary greatly in lithology and grain-size, both vertically and areally. Accordingly, the hydraulic properties of these deposits can differ greatly over short distances, both laterally and vertically.

The alluvial aquifer consists of a heterogeneous mixture of gravel, sand, silt, clay and sandy-clay. Conceptually the aquifer system in the delta is an unconfined aquifer and more than $500 \mathrm{~m}$ thick. Recharge occurs by means of precipitation and infiltration at the top of the delta. The recharge rate is determined as $35.23 \mathrm{~mm}$ by using Visual HELP model [4].

\section{Materials and Methods}

Salty water can be detected directly in observation wells by electrical electrodes or by sampling, or indirectly by geoelectrical methods [5]. In this study, the direct method by sampling is used. AquaChem software is used and it allows comparing a sample (Sea water sample) to another multiple samples (all groundwater samples). This comparation uses a linear regression algorithm to generate the correlation coefficient and the Euclidean distance between Sea water and all other samples.

For chemical analysis, a total of 16 water samples from the Göksu Delta (9 from alluvial aquifer, 4 from limestone aquifer, 1 from Paradeniz Lake, 1 from Akgöl and 1 from Mediterranean Sea) were obtained from 2006 to 2008 by four separate sampling campaigns at the sampling points shown in Figure 1. Table 1 summarizes the chemical analysis results for water samples collected from the Göksu Delta and the Table 2 shows the chemical characters of waters. The $\mathrm{pH}$, temperature $(\mathrm{T})$, electrical conductivity (EC) and salinity (sal) were measured at 25 sampling points in four different periods between 2006 and 2008 (Table 3).

Water samples obtained from the wells are from various depths because the wells in the area vary greatly in depth. Average well depth is $5 \mathrm{~m}$ for hand dug wells (showed with DSI) and 30-35 m for drilled wells (shown with $\mathrm{ME}$ ). Electrical conductivity (EC), temperature (T), salinity (sal) and $\mathrm{pH}$ were monitored during pumping, and samples were collected only when values were stabilized or after at least three well volumes had been purged. Measurements of EC and $\mathrm{pH}$ were made in the field using a $\mathrm{pH} / \mathrm{Cond} 340 \mathrm{i}$ WTW meter. For the $\mathrm{pH}$ measurements the electrode was calibrated against $\mathrm{pH}$ buffers at each location.

Cations were analyzed by inductively coupled plasma (ICP) and anions by ion chromatography (IC). $\mathrm{SiO}_{2}$ was analyzed mainly by visible spectrophotometer. Bicarbonates were determined by titration in the laboratory. Samples were analyzed in the laboratory of General Directorate of Mineral Research and Exploration (MTA) of Turkey in Ankara. 
Followed by water quality analysis, a vector-based GIS software package MapInfo was used to map, query, and analyze the data in this study. GIS is an effective tool for storing large volumes of data that can be correlated spatially and retrieved for the spatial analysis and integration to produce the desirable output. GIS has been used by scientists of various disciplines for spatial queries, analysis and integration for the last three decades [6]. GIS is a powerful tool and has great promise for use in environmental problem solving. Most environmental problems have an obvious spatial dimension and spatially distributed models can interact with GIS [7]. Troge [8] reported that this computer-based tool has allowed successful integration of water quality variables into a comprehensible format.

\section{Results and Discussion}

The groundwater samples collected from the Göksu
Delta are colorless, odorless and free from turbidity. In Table 1, the results of ion concentrations of groundwater for July 2006 are presented. The Table $\mathbf{2}$ shows the chemical types of groundwater from different aquifers and places.

Paradeniz Lake is a saltwater lagoon connected to the sea and the chemistry of Paradeniz water is similar to the Mediterranean Seawater. The EC values of sea water and lake water are $53000 \mu \mathrm{S} / \mathrm{cm}$ and $48000 \mu \mathrm{S} / \mathrm{cm}$, respectively.

The types of groundwater from alluvial aquifer are $\mathrm{Ca}-\mathrm{Mg}-\mathrm{HCO}_{3}$, but in the region where sea water intrusion occurs it changes and the $\mathrm{Na}$ and $\mathrm{Cl}$ ions are added in the types of groundwater (Table 2). The similar occurrence can be observed in the groundwater from the limestone aquifer. The chemical types of groundwater are $\mathrm{Ca}-\mathrm{HCO}_{3}$ or $\mathrm{Ca}-\mathrm{Mg}-\mathrm{HCO}_{3}$ and they change to $\mathrm{Ca}-$ $\mathrm{Na}-\mathrm{Mg}-\mathrm{HCO}_{3}-\mathrm{Cl}$ in the vicinity of seawater mixing regions.

Table 1. Results of the chemical analyses. Concentrations are in milligram per liter

\begin{tabular}{|c|c|c|c|c|c|c|c|c|c|c|c|c|c|c|c|c|}
\hline \multirow[t]{2}{*}{$\begin{array}{l}\text { Sam- } \\
\text { pling }\end{array}$} & ME-1 & ME-12 & ME-20 & $\mathrm{ME}-23$ & $\mathrm{ME}-24$ & ME-26 & ME-28 & ME-3 & ME-18 & ME-14 & ME-15 & ME-16 & $\mathrm{ME}-21$ & Akgöl & Paradeniz & $\begin{array}{c}\text { Sea } \\
\text { water }\end{array}$ \\
\hline & \multicolumn{9}{|c|}{ Alluvial aquifer } & \multicolumn{4}{|c|}{ Limestone aquifer } & \multicolumn{3}{|c|}{ Surface water } \\
\hline $\mathrm{pH}$ & 7.39 & 7.56 & 7.76 & 8.12 & 8.4 & 7.84 & 7.45 & 7.42 & 7.17 & 6.94 & 7.17 & 7.2 & 7.29 & 8.3 & 8.05 & 7.91 \\
\hline $\mathrm{T}$ & 23.4 & 21.3 & 21.5 & 22 & 21.6 & 26 & 21.5 & 23.2 & 21.5 & 22.3 & 20.1 & 21.2 & 22.1 & 33.9 & 31 & 29.2 \\
\hline $\mathrm{EC}$ & 1220 & 1988 & 925 & 2810 & 1031 & 711 & 598 & 756 & 719 & 1025 & 997 & 558 & 893 & 439 & 45300 & 53500 \\
\hline sal & 0.4 & 0.9 & 0.2 & 1.3 & 0.3 & 0.1 & 0 & 0.1 & 0.1 & 0.3 & 0.3 & 0 & 0.2 & 0 & 29.6 & 35.5 \\
\hline DO & 5.2 & 6.6 & 6.7 & 6.9 & 7.2 & 7.5 & 7.2 & 6.9 & 6.6 & 7 & 8.1 & 6.9 & 7.2 & 5.5 & 4.9 & 4.7 \\
\hline $\mathrm{NO}_{2}$ & 0.1 & 0 & 0 & 0.26 & 0 & 0 & 0 & 0.26 & 0 & 0 & 0 & 0 & 0 & 0 & 0 & 0 \\
\hline $\mathrm{NO}_{3}$ & 15 & 1.8 & 15.9 & 10.6 & 5.3 & 9.3 & 11.9 & 9.7 & 14.2 & 9.74 & 6.2 & 12.4 & 32.34 & 6.64 & 0 & 6.64 \\
\hline $\mathrm{NH}_{3}$ & 0.13 & 0 & 0.07 & 0 & 0.43 & 0 & 0 & 0 & 0.02 & 0 & 0 & 0.012 & 0.012 & 0.34 & 4.01 & 4.01 \\
\hline $\mathrm{PO}_{4}$ & 1.35 & 0.21 & 0.23 & 0.45 & 0.24 & 0.13 & 0.42 & 0.61 & 1.86 & 0.28 & 0.54 & 0.13 & 0.35 & 0.88 & 0.39 & 0.2 \\
\hline $\mathrm{P}$ & 1 & 0.6 & 0.2 & 0.5 & 0.3 & 0.2 & 1.2 & 0.6 & 1.1 & 0.4 & 0.6 & 0.1 & 0.4 & 1.4 & 0.2 & 0.7 \\
\hline $\mathrm{Br}$ & 1.05 & 0.47 & 0.5 & 1.93 & 0.47 & 2.64 & 3.38 & 0.53 & 1.63 & 0.64 & 0.59 & 1.54 & 0.58 & 0.72 & 0.42 & 0.58 \\
\hline I & 0.1 & 0.5 & 0.3 & 0.3 & 0.1 & 0 & 0.5 & 0.1 & 0.1 & 0.1 & 0.1 & 0.2 & 0.2 & 0.2 & 3 & 0.2 \\
\hline F & 0.93 & 0.46 & 0 & 1.97 & 1.16 & 0.21 & 0.3 & 0.22 & 0.08 & 0 & 0.56 & 0.34 & 0.45 & 0.83 & 0.81 & 1.96 \\
\hline $\mathrm{Na}$ & 150 & 361 & 121 & 535 & 213 & 70.9 & 16.8 & 42.2 & 29.6 & 73.6 & - & 10.4 & 48.4 & 21.7 & 9556 & 10934 \\
\hline $\mathrm{K}$ & 6.54 & 21.9 & 3.25 & 20 & 4.26 & 4.98 & 1.97 & 2.79 & 2.38 & 2.89 & - & 1.43 & 3.42 & 1.86 & 396 & 485 \\
\hline $\mathrm{Ca}$ & 66.7 & 32.8 & 33.5 & 17.1 & 18.3 & 31.3 & 52.6 & 64.9 & 74.9 & 118 & - & 64.1 & 61.9 & 36.5 & 350 & 373 \\
\hline $\mathrm{Mg}$ & 42.8 & 25.2 & 26.9 & 18.3 & 5.69 & 25.8 & 41.6 & 40.4 & 22.7 & 14 & - & 24.6 & 40.9 & 23.8 & 717 & 822 \\
\hline $\mathrm{HCO}_{3}$ & 546 & 340 & 261 & 255 & 255 & 194 & 219 & 407 & 267 & 370 & - & 285 & 279 & 213 & 128 & 140 \\
\hline $\mathrm{Cl}$ & 78.4 & 418 & 149 & 696 & 157 & 102 & 51.7 & 29 & 54.2 & 136 & - & 15 & 94.2 & 22.5 & 15177 & 17929 \\
\hline SO4 & 125 & 100 & 40.3 & 91.4 & 40.7 & 21.7 & 47.6 & 58 & 32.2 & 21 & - & 27.4 & 41.3 & 34.4 & 2470 & 2915 \\
\hline KOI & 21 & 22 & 1 & 28 & 3 & 3 & 10 & 2 & 2 & 19 & - & 2 & 12 & 16 & 1050 & 1000 \\
\hline $\mathrm{Mn}$ & 0 & 0 & 0 & 0 & 0 & 0 & 0 & 0 & 0 & 0 & 0 & 0 & 0 & 0 & 0 & 0 \\
\hline $\mathrm{Fe}$ & 7.5 & 0.2 & 3.41 & 5.5 & 5.5 & 5.5 & 4.16 & 0.8 & 2.07 & 0 & 0 & 0.03 & 5.5 & 0.5 & 0.5 & 0.06 \\
\hline $\mathrm{Cu}$ & 0.27 & 0.37 & 0.41 & 0.14 & 0.35 & 0.26 & 0.17 & 0.29 & 0.24 & 0 & 0 & 0 & 0.21 & 0.9 & 0.4 & 0.77 \\
\hline $\mathrm{SiO}_{2}$ & 48 & 12 & 20.6 & 2.8 & 5.5 & 17.7 & 28 & 11 & 10 & 2.6 & 2.8 & 8.2 & 29 & 17.4 & 7 & 0.14 \\
\hline Mo & 0.3 & 0 & 0 & 0 & 0 & 0 & 0.1 & 0 & 0 & 0.6 & 0 & 0 & 0 & 0 & 0 & 0 \\
\hline $\mathrm{Cr}$ & 0.047 & 0.026 & 0 & 0 & 0 & 0 & 0 & 0.08 & 0 & 0 & 0 & 0 & 0 & 0 & 0 & 0.048 \\
\hline
\end{tabular}


Table 2. The chemical characters of ground waters in the Göksu delta.

\begin{tabular}{ccc}
\hline Sample number & Aquifer & Chemical character \\
\hline ME-1 & Alluvial & Na-Mg-Ca-HCO3 \\
ME-12 & Alluvial & Na-Cl-HCO3 \\
ME-18 & Alluvial & Ca-Mg-HCO3-Cl \\
ME-20 & Alluvial & Na-Mg-HCO3-Cl \\
ME-23 & Alluvial & Na-Cl \\
ME-24 & Alluvial & Na-Cl-HCO3 \\
ME-26 & Alluvial & Na-Mg-Ca-HCO3-Cl \\
ME-28 & Alluvial & Mg-Ca-HCO3-Cl \\
ME-3 & Alluvial & Mg-Ca-Na-HCO3 \\
ME-14 & Limestone & Ca-Na-HCO3-Cl \\
ME-16 & Limestone & Ca-Mg-HCO3 \\
ME-21 & Limestone & Mg-Ca-Na-HCO3-Cl \\
\hline
\end{tabular}

With very few exceptions, sample points fall within the mixing field of the Piper diagram (Figure 2). Three regions are distinguished in the diagram. First region where the samples ME3 and ME 28 are placed show the aquifer region where the seawater intrusion does not occurred. The second place, the central of the Piper diagram where the samples ME1 and ME 20 are shows the aquifer region where the sea water impact begins. The third place is very close to the Sea water sample, where the samples ME 12 and ME 23 are shows the aquifer region where the sea water mixing with sea water occurs. The samples ME12 and ME23 are very close to the Sea and Paradeniz waters.

The other indicators for the detection of sea water influence are T, EC and sal values. Table 3 contains the results of $\mathrm{pH}, \mathrm{T}, \mathrm{EC}$ and sal measurements for four periods between 2006 and 2008. By using MapInfo, many

Table 3. The values of electrical conductivity and salinity between 2006 and 2008 .

\begin{tabular}{|c|c|c|c|c|c|}
\hline Kuyu No & Date & $\mathrm{pH}$ & $\mathrm{T}\left({ }^{\circ} \mathrm{C}\right)$ & $\mathrm{EC}(\mu \mathrm{S} / \mathrm{cm})$ & sal \\
\hline \multirow{2}{*}{ DSI-2 } & $07 / 2006$ & 6.85 & 28.4 & 598 & 0 \\
\hline & $06 / 2007$ & 6.80 & 27.9 & 641 & 0.1 \\
\hline \multirow{4}{*}{ DSI-20 } & $07 / 2006$ & 7.34 & 28.2 & 437 & 0 \\
\hline & $06 / 2007$ & 7.83 & 26.9 & 459 & 0 \\
\hline & $01 / 2008$ & 7.93 & 12.7 & 448 & 0 \\
\hline & $04 / 2008$ & 8.60 & 20.5 & 667 & 0.1 \\
\hline \multirow{4}{*}{ DSI-35 } & $07 / 2006$ & 7.47 & 24.7 & 657 & 0.1 \\
\hline & $06 / 2007$ & 7.18 & 24.0 & 762 & 0.1 \\
\hline & $01 / 2008$ & 8.02 & 16.1 & 1295 & 0.4 \\
\hline & $04 / 2008$ & 8.00 & 17.8 & 1308 & 0.4 \\
\hline \multirow{4}{*}{ DSI-38 } & $07 / 2006$ & 7.40 & 21.1 & 920 & 0.2 \\
\hline & $06 / 2007$ & 7.96 & 21.8 & 856 & 0.2 \\
\hline & $01 / 2008$ & 7.90 & 19.1 & 864 & 0.2 \\
\hline & $04 / 2008$ & 8.30 & 19.5 & 930 & 0.2 \\
\hline \multirow{4}{*}{ DSI-4 } & $07 / 2006$ & 7.32 & 25.9 & 531 & 0 \\
\hline & $06 / 2007$ & 7.10 & 27.8 & 481 & 0 \\
\hline & $01 / 2008$ & 7.90 & 14.3 & 620 & 0 \\
\hline & $04 / 2008$ & 8.20 & 19.8 & 987 & 0.3 \\
\hline \multirow{4}{*}{ ME-10 } & $07 / 2006$ & 7.40 & 20.2 & 802 & 0.2 \\
\hline & $06 / 2007$ & 7.93 & 27.0 & 453 & 0 \\
\hline & $01 / 2008$ & 7.70 & 15.0 & 465 & 0 \\
\hline & $04 / 2008$ & 8.80 & 20.8 & 684 & 0.1 \\
\hline \multirow{4}{*}{ ME-11 } & $07 / 2006$ & 7.80 & 23.2 & 1416 & 0.5 \\
\hline & $06 / 2007$ & 7.85 & 22.1 & 1425 & 0.5 \\
\hline & $01 / 2008$ & 8.20 & 12.3 & 1576 & 0.6 \\
\hline & $04 / 2008$ & 8.40 & 21.8 & 1825 & 0.8 \\
\hline \multirow{4}{*}{ ME-13 } & $07 / 2006$ & 7.06 & 25.5 & 850 & 0.2 \\
\hline & $06 / 2007$ & 6.90 & 25.0 & 904 & 0.2 \\
\hline & $01 / 2008$ & 7.30 & 14.8 & 866 & 0.2 \\
\hline & $04 / 2008$ & 7.48 & 20.6 & 1024 & 0.3 \\
\hline \multirow{4}{*}{ ME-2 } & $07 / 2006$ & 8.10 & 23.7 & 1085 & 0.3 \\
\hline & $06 / 2007$ & 7.90 & 26.6 & 1058 & 0.3 \\
\hline & $01 / 2008$ & 8.31 & 8.8 & 1132 & 0.3 \\
\hline & $04 / 2008$ & 8.70 & 27.1 & 1247 & 0.4 \\
\hline ME-25 & $07 / 2006$ & 7.94 & 20.7 & 434 & 0 \\
\hline
\end{tabular}




\begin{tabular}{|c|c|c|c|c|c|}
\hline & $06 / 2007$ & 8.13 & 21.7 & 435 & 0 \\
\hline & $01 / 2008$ & 8.50 & 19.4 & 699 & 0.1 \\
\hline & $04 / 2008$ & 8.38 & 20.5 & 527 & 0 \\
\hline \multirow{4}{*}{ ME-27 } & $07 / 2006$ & 7.20 & 21.4 & 788 & 0.1 \\
\hline & 06/2007 & 6.87 & 22.1 & 914 & 0.2 \\
\hline & $01 / 2008$ & 7.80 & 18.6 & 1212 & 0.4 \\
\hline & $04 / 2008$ & 7.48 & 21.4 & 843 & 0.2 \\
\hline \multirow{4}{*}{ ME-4 } & $07 / 2006$ & 7.72 & 21.4 & 1510 & 0.6 \\
\hline & 06/2007 & 7.30 & 22.6 & 970 & 0.3 \\
\hline & $01 / 2008$ & 7.85 & 20.0 & 2030 & 0.9 \\
\hline & $04 / 2008$ & 8.13 & 21.1 & 2080 & 0.9 \\
\hline \multirow{4}{*}{ ME-5 } & $07 / 2006$ & 7.54 & 22.8 & 2260 & 1.0 \\
\hline & $06 / 2007$ & 7.43 & 26.6 & 1430 & 0.5 \\
\hline & $01 / 2008$ & 7.73 & 18.8 & 2930 & 1.4 \\
\hline & $04 / 2008$ & 8.04 & 21.5 & 1575 & 0.6 \\
\hline \multirow{4}{*}{ ME-9 } & $07 / 2006$ & 8.48 & 20.8 & 716 & 0.1 \\
\hline & $06 / 2007$ & 7.93 & 23.3 & 837 & 0.2 \\
\hline & $01 / 2008$ & 8.70 & 16.0 & 814 & 0.2 \\
\hline & $04 / 2008$ & 9.03 & 20.3 & 1075 & 0.3 \\
\hline \multirow{4}{*}{ ME-8-A } & $07 / 2006$ & 8.10 & 21.5 & 1476 & 0.6 \\
\hline & 06/2007 & 8.45 & 21.0 & 1490 & 0.6 \\
\hline & $01 / 2008$ & 8.19 & 18.5 & 1546 & 0.6 \\
\hline & $04 / 2008$ & 8.50 & 21.2 & 1755 & 0.7 \\
\hline \multirow{4}{*}{ ME-1 } & $07 / 2006$ & 7.39 & 23.4 & 1220 & 0.4 \\
\hline & 06/2007 & 7.55 & 23.9 & 1146 & 0.4 \\
\hline & $01 / 2008$ & 7.67 & 20.1 & 1412 & 0.5 \\
\hline & $04 / 2008$ & 7.80 & 22.6 & 1710 & 0.6 \\
\hline \multirow{4}{*}{ ME-12 } & $07 / 2006$ & 7.56 & 21.3 & 1988 & 0.9 \\
\hline & $06 / 2007$ & 7.62 & 22.9 & 1894 & 0.8 \\
\hline & $01 / 2008$ & 7.90 & 18.7 & 1404 & 0.5 \\
\hline & $04 / 2008$ & 8.50 & 20.1 & 1470 & 0.5 \\
\hline \multirow{4}{*}{ ME-20 } & $07 / 2006$ & 7.76 & 21.5 & 925 & 0.2 \\
\hline & $06 / 2007$ & 7.73 & 23.1 & 751 & 0.1 \\
\hline & $01 / 2008$ & 7.92 & 19.1 & 925 & 0.2 \\
\hline & $04 / 2008$ & 8.27 & 20.5 & 728 & 0.1 \\
\hline \multirow{4}{*}{ ME-23 } & $07 / 2006$ & 8.12 & 22.0 & 2810 & 1.3 \\
\hline & 06/2007 & 8.16 & 22.9 & 2830 & 1.4 \\
\hline & $01 / 2008$ & 8.80 & 19.2 & 3460 & 1.7 \\
\hline & $04 / 2008$ & 8.30 & 22.0 & 3420 & 1.7 \\
\hline ME-24 & $07 / 2006$ & 8.40 & 21.6 & 1031 & 0.3 \\
\hline \multirow{4}{*}{ ME-26 } & $07 / 2006$ & 7.84 & 26.0 & 711 & 0.1 \\
\hline & 06/2007 & 7.57 & 28.0 & 780 & 0.1 \\
\hline & $01 / 2008$ & 8.50 & 14.5 & 1004 & 0.3 \\
\hline & $04 / 2008$ & 8.13 & 21.4 & 3420 & 1.7 \\
\hline \multirow{4}{*}{ ME-28 } & $07 / 2006$ & 7.45 & 21.5 & 598 & 0 \\
\hline & 06/2007 & 7.07 & 21.7 & 601 & 0 \\
\hline & $01 / 2008$ & 8.90 & 18.5 & 3050 & 1.5 \\
\hline & $04 / 2008$ & 7.73 & 21.1 & 2830 & 1.3 \\
\hline \multirow{4}{*}{ ME-3 } & $07 / 2006$ & 7.42 & 23.2 & 756 & 0.1 \\
\hline & $06 / 2007$ & 7.20 & 24.3 & 739 & 0.1 \\
\hline & $01 / 2008$ & 7.60 & 15.2 & 712 & 0.1 \\
\hline & $04 / 2008$ & 7.65 & 26.8 & 1091 & 0.3 \\
\hline \multirow{4}{*}{ ME-18 } & $07 / 2006$ & 7.17 & 21.5 & 719 & 0.1 \\
\hline & 06/2007 & 6.95 & 30.9 & 753 & 0.1 \\
\hline & $01 / 2008$ & 7.90 & 11.7 & 932 & 0.2 \\
\hline & $04 / 2008$ & 8.03 & 20.3 & 1003 & 0.3 \\
\hline
\end{tabular}




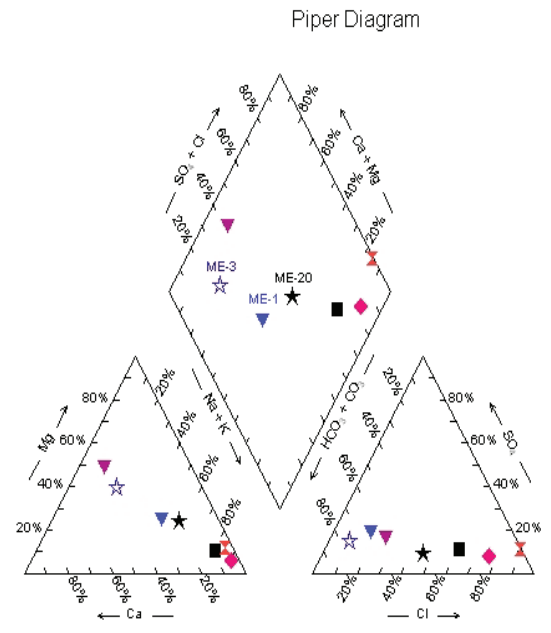

Figure 2. Piper diagram.

thematic maps are produced and by overlaying these maps sea water affected areas are determined.

The extent of saltwater affect is reflected by the distribution of salinity and electrical conductivity as an equiconcentration map (Figures 4-9). The periodical sal and EC measurements are used to show the development of saltwater mixing in space for four selected times.

The thematic map of groundwater temperature shows that in the region the temperature is increased in the places where the sea water mixing occurs. These regions are the southern part of Delta and in the vicinity of Sultanoğlu and Altınkum towns. In these regions the groundwater temperature increased until to $25-26^{\circ} \mathrm{C}$ (Figure 3).
EC values vary between 434 and $3460 \mu \mathrm{S} / \mathrm{cm}$ and sạl values between $0-1.7$.

Table 4. The results of statistical (comparation) analyses.

\begin{tabular}{lcccc}
\hline \multicolumn{5}{c}{ Main Sample: ME-6, 17.07.2006 } \\
\hline Index & Sample & Corr Coeff & \multicolumn{2}{c}{ Euclidean distance } \\
32 & ME-6, & 1.0 & 0.0 & 7 \\
31 & ME-22, & 1.0 & 3112.905 & 7 \\
14 & ME-23, & 0.941 & 20349.32 & 7 \\
34 & ME-8, & 0.882 & 20773.57 & 7 \\
9 & ME-12, & 0.76 & 20672.79 & 7 \\
15 & ME-24, & 0.486 & 20978.22 & 7 \\
13 & ME-20, & 0.319 & 21031.26 & 7 \\
22 & ME-26, & 0.239 & 21098.99 & 7 \\
25 & ME-14, & -0.006 & 21069.52 & 7 \\
33 & ME-7, & -0.014 & 21082.51 & 7 \\
28 & ME-21, & -0.069 & 21113.98 & 7 \\
6 & ME-1, & -0.169 & 21067.24 & 7 \\
11 & ME-18, & -0.223 & 21159.15 & 7 \\
24 & ME-28, & -0.244 & 21165.09 & 7 \\
30 & ME-19, & -0.297 & 21189.85 & 7 \\
23 & ME-3, & -0.315 & 21171.34 & 7 \\
27 & ME-16, & -0.362 & 21203.06 & 7 \\
29 & ME-17, & -0.384 & 21209.38 & 7 \\
\hline
\end{tabular}

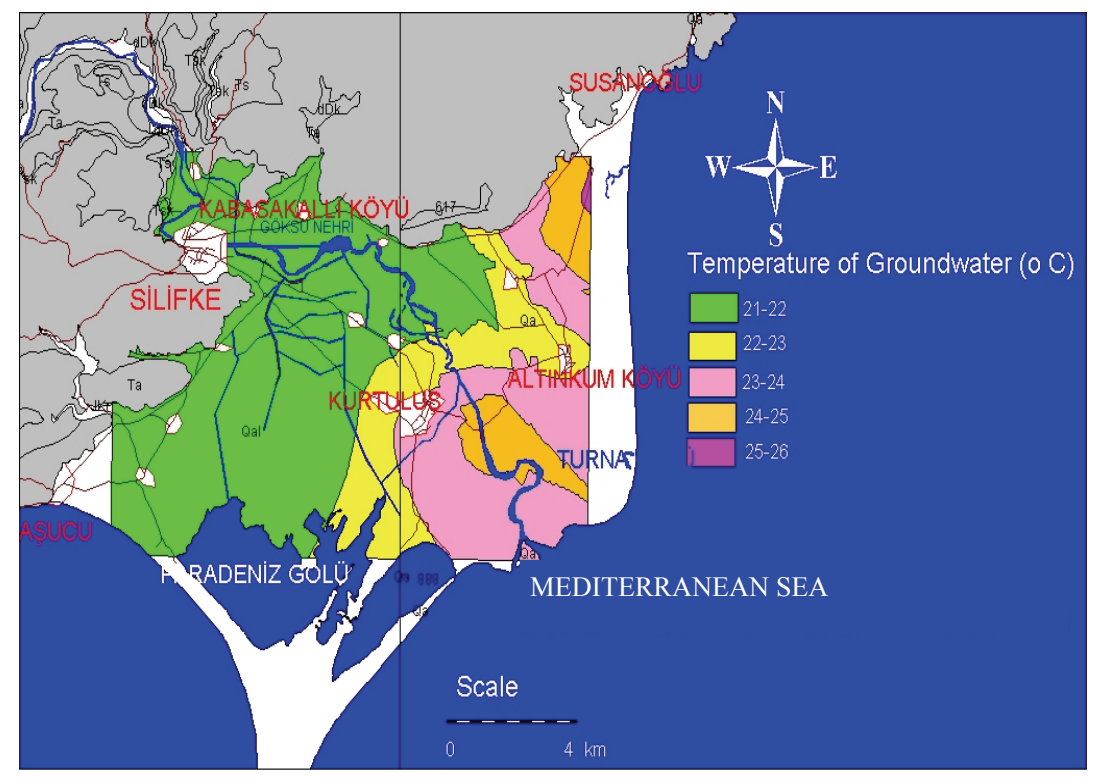

Figure 3. Temperature of groundwater for 2006. 


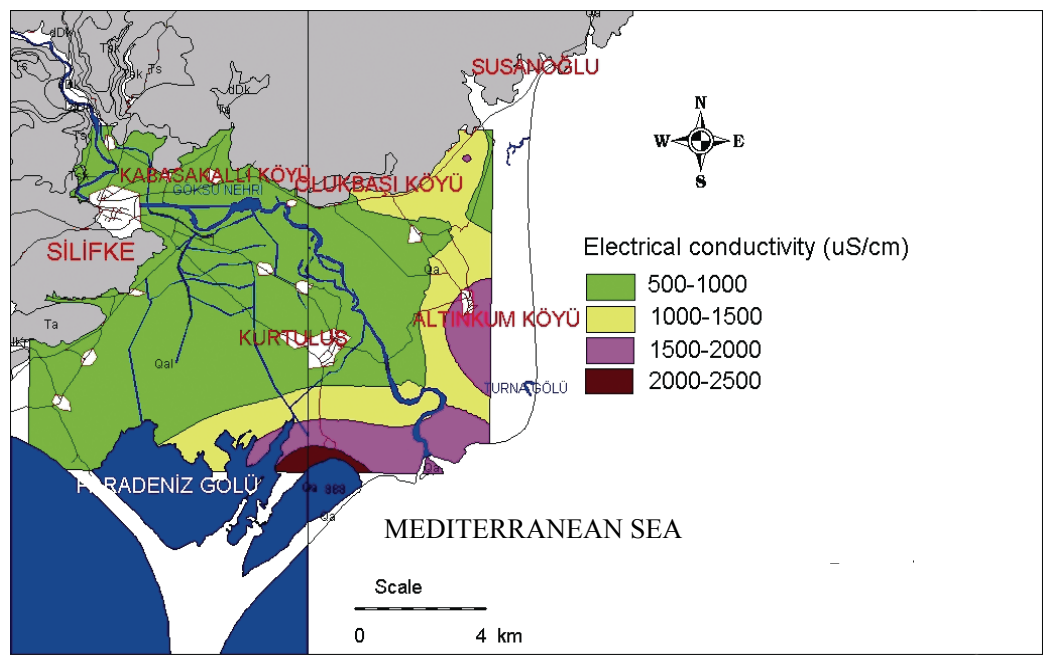

Figure 4. Thematic map for electrical conductivity (2006).

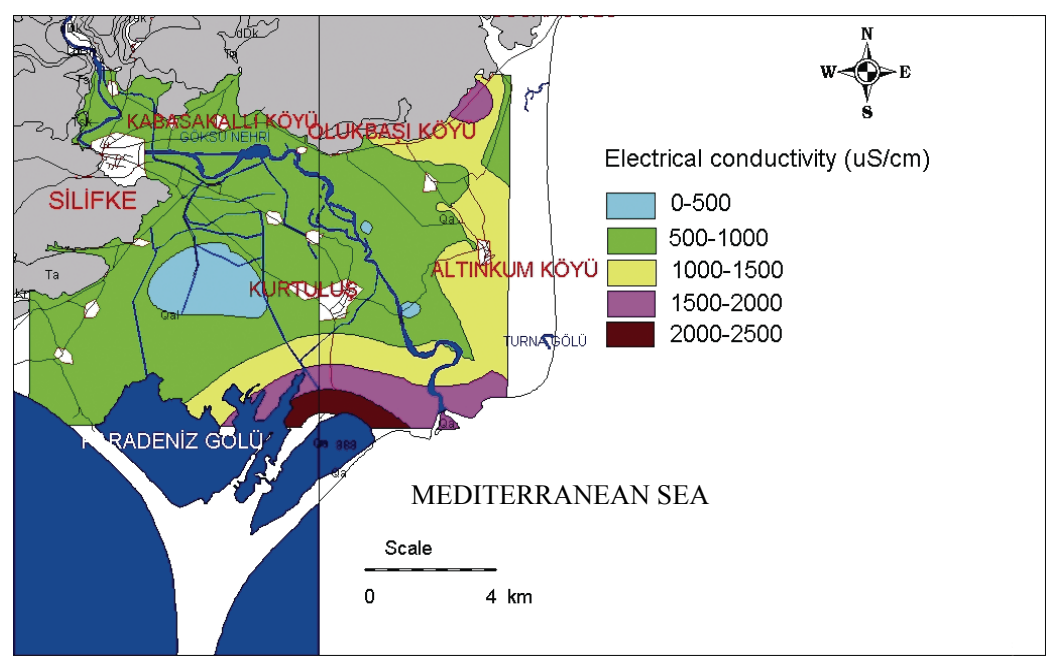

Figure 5. Thematic map for electrical conductivity (2007).

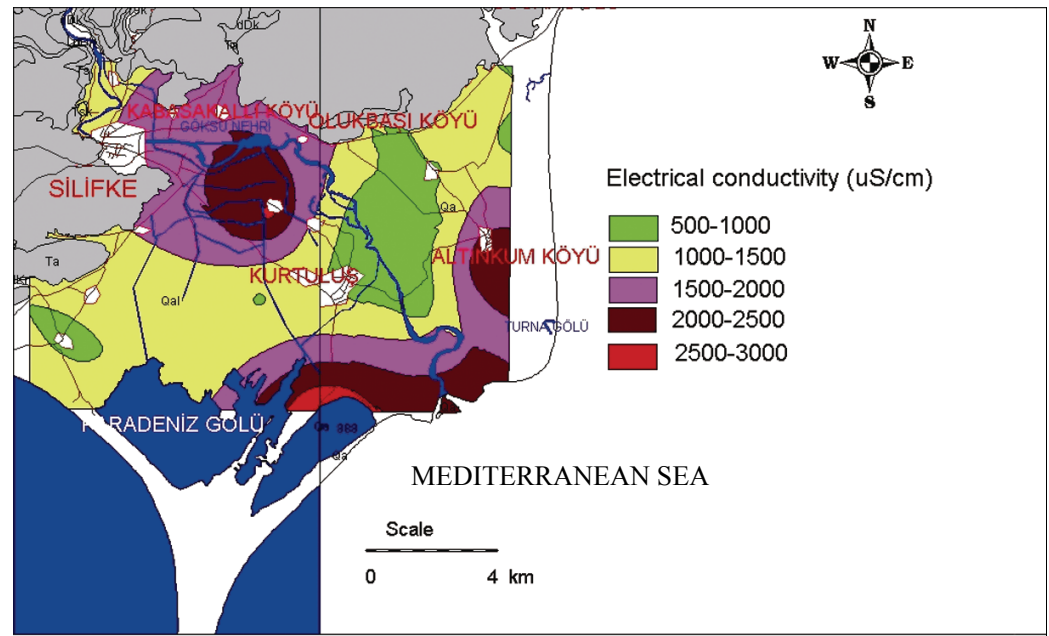

Figure 6. Thematic map for electrical conductivity (2008). 


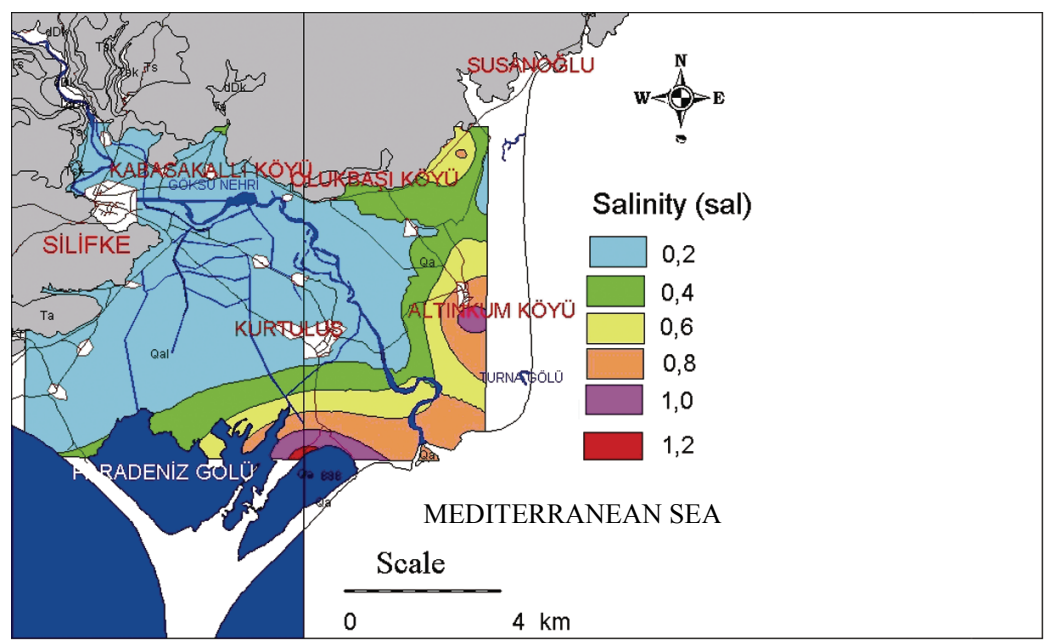

Figure 7. Thematic map for salinity (2006).

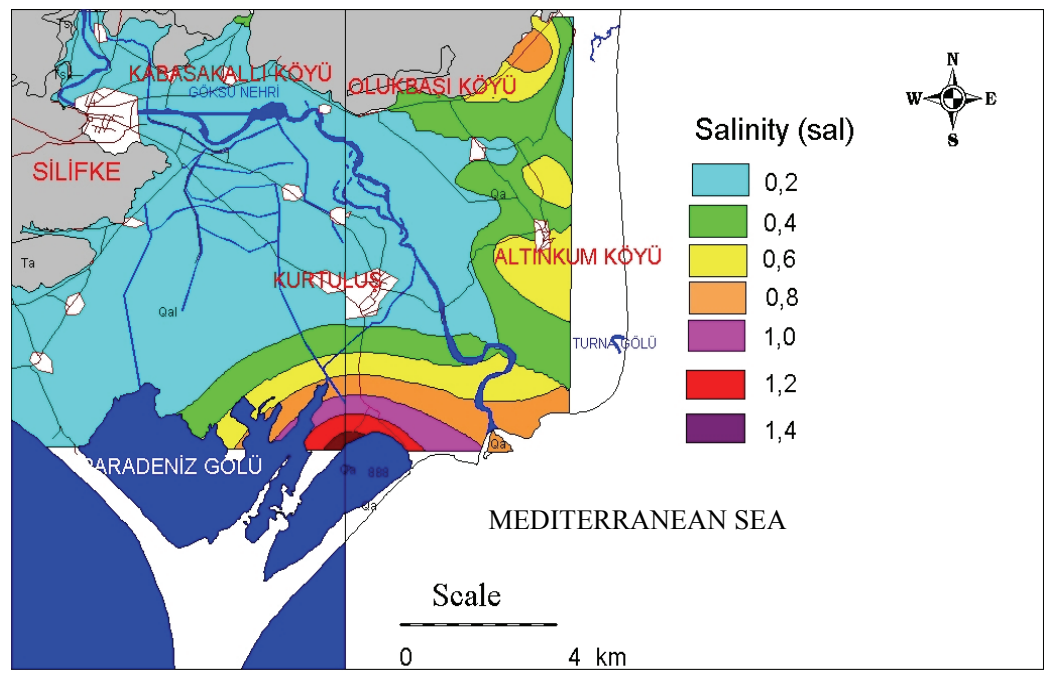

Figure 8. Thematic map for salinity (2007).

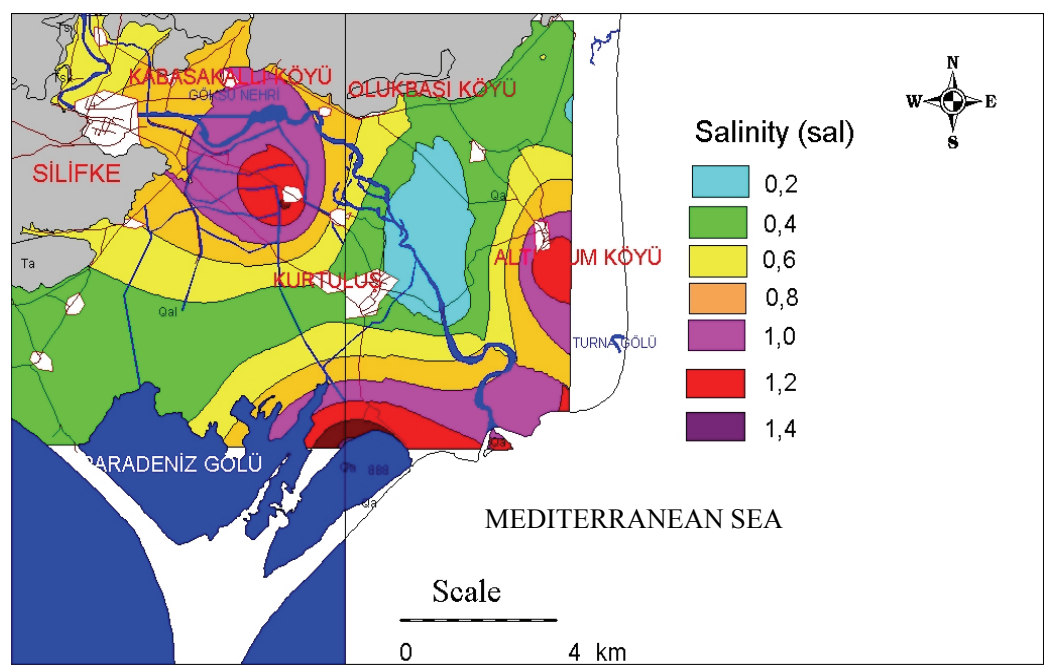

Figure 9. Thematic map for salinity (2008). 
EC and sal contours prevailing in the delta, for 2006, 2007 and 2008, are presented in Figures 4-9, respectively. The EC and sal thematic maps give almost the same picture for all periods. The affect of seawater is reflected in a high value of EC (over $1500 \mu \mathrm{S} / \mathrm{cm}$ ) and sal (over 0.6) of groundwater. It is obvious that groundwater quality is seriously degradated in the region. These thematic maps indicate that sea water is affected almost more than $2 \mathrm{~km}$ in inland.

The natural recharge of the aquifer seems not to be quantitative adequate to improve significantly the water quality.

Owing to increasing demand for water, groundwater has been pumped to over-exploitation and natural equilibrium has thus been disturbed. This has resulted in seawater mixing reaching inland aquifers.

\section{Conclusions}

Groundwater is an indispensable resource for water supply for the towns on Göksu Delta, for the urban and for sources has seriously impeded the development of industry, agriculture and the improvement of the people's living standards in this internationally protected region.

The chemistry and the chemical types of groundwater indicate the sea water intrusion in Göksu delta. The chemical characters of waters in the region affected by the sea water are changed. The statistical comparation analysis supports also this event.

With the equi-concentration mapping of $\mathrm{EC}$ and sal the extent of the seawater pollution in the aquifer was determined. The seawater mixing reached more than 2 $\mathrm{km}$ inland in the north and east direction. The salinity and electrical conductivity measurements and the thematic maps indicate that the origin of groundwater salinity in Göksu Delta is due to seawater intrusion which resulted from intensive pumping.

\section{Acknowledgements}

The author would like to acknowledge the Scientific and Technological Research Council of Turkey, (TUBITAK) Ankara, for financing this project (105Y285).

\section{References}

[1] Z. Ayas, N. Barlas Emir and D. Kolankaya, "Determination of Organochlorine Pesticide Residues in Various Environments and Organisms in Göksu Delta, Turkey," Aquatic Toxicology, Vol. 39, No. 2, 1997, pp. 171-181.

[2] Z. Demirel, "Monitoring of Heavy Metal Pollution of Groundwater in a Phreatic Aquifer in Mersin-Turkey," Environmental Monitoring and Assessment, Vol. 132,

No. 1-3, 2007, pp. 15-23.

[3] F. B. J. Glen, A. K. Godley and A. C. Broderick, "Marine Turtle Nesting in the Goksu Delta, Turkey, 1996," Mar Turtle Newsl, Vol. 77, 1997, pp. 17-19.

[4] Z. Demirel, "Göksu Deltası Yeraltısuyu Kalitesinin Fotometrik Ölçümler İle Belirlenmesi ve Su KalitesiCoğrafi Bilgi Sisteminin Oluşturulması," TUBITAK Project, No. 105Y285, 2008.

[5] A. J. Melloul and L. C. Goldenberg, "Monitoring of Seawater Mixing in Coastal Aquifers: Basic and Local Concerns," Journal of Environmental Management, Vol. 51, No. 1, 1997, pp. 73-86.

[6] P. A. Burrough and R. A. McDonnell, "Principles of Geographical Information Systems," Oxford University Press, Oxford, 1998, p. 333.

[7] M. F. Goodchild, B. O. Parks and L. T. Steyaert, "Environmental Modeling with GIS," Oxford University Press, Oxford, 1993, p. 520.

[8] M. F. Troge, "A GIS Strategy for Lake Management Issues," National Conference on Environmental Problem-Solving with Geographic Information Systems, Cincinnati, 1994. 